v.9, n.4

Vitória-ES, Oct.-Dec 2012

p. 87-102 ISSN 1808-2386 DOI:http://dx.doi.org/10.15728/bbr.2012.9.4.4

A Direct test of the permanent income hypothesis: the brazilian case*

\author{
Fabio Augusto Reis Gomes ${ }^{\dagger}$ \\ Fucape Business School
}

\begin{abstract}
This paper aims to analyze whether the permanent income hypothesis (PIH) can explain the evolution of consumption in Brazil using a direct test based on consumption revisions induced by income innovations. Under PIH, consumption should react to income changes inasmuch as current income has information about the permanent income. To measure this connection, an $\operatorname{ARIMA}(p, 1, q)$ model was estimated for current income and, as a result, it was possible to check if revisions in consumption and permanent income are similar. At the end, the PIH was rejected.
\end{abstract}

Key-words: Permanent income hypothesis; income innovations; consumption revisions.

Received 03/01/2012; revised 06/25/2012; accepted 06/27/2012; published 11/16/2012.

*Corresponding author:

${ }^{\dagger}$. Doctor in Economics at Getulio Vargas Foundation

Affiliation: Professor at Fucape Business School.

Address: Av. Fernando Ferrari, 1358. Boa Vista.

Vitória-ES.

E-mail: fabiogomes@ fucape.br

Telephone: (27) 4009-4444

Editor's note: This paper was accepted by Bruno Funchal.

\title{
$(\infty)) \mathrm{BY}$
}

This work was licensed with a Creative Commons License - Attribution 3.0 Not adapted 


\section{INTRODUCTION}

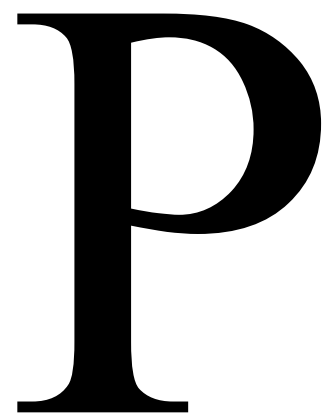

ermanent income hypothesis - hereafter PIH - posits that consumers are forward-looking and base their consumption on their permanent income, which is defined as the expected permanent discounted value of their lifetime resources. Therefore, consumption revisions should be based on innovations of permanent income instead of current income innovations. However, innovations in current income are relevant inasmuch as they induce changes in permanent income. To measure this connection, it is necessary to model current income. As a result, it is possible to check if revisions in consumption and permanent income are similar. This strategy was named by Dejuan et al (2004) as a direct test of the PIH.

Bilson (1980) seems to be the pioneer of this approach. The author performed the test for US, UK and Germany and his findings support the PIH. However, revisiting the US case, Flavin (1981) found the opposite result. A common drawback in these works, pointed out by Weissenberger (1986), is the assumption that changes in consumption are serially uncorrelated. Indeed, Weissenberger (1986) assumed an ARMA structure along with an updated data set for UK and Germany, and refuted Bilson's results for both countries. It is important to mention that Mankiw and Shapiro (1985) showed that tests of the PIH can be severely biased by imposing trend stationarity when the data is difference-stationary; and, Weissenberger (1986) adopted the trend stationarity case. Dawson et al (2001) performed the direct test for a group of 85 countries, using Pen Word Table data. However, their approach is not able to test the PIH for each country separately. Their results suggest that industrial countries and, more specifically, countries with high data quality support the PIH. Dejuan et al (2004) analyzed 48 US states and the results provided some support for the PIH across different states. The authors conducted unit root tests prior to implementation of the PIH test.

The purpose of this paper is to conduct a direct test of the PIH, taking into account the order of integration of income and consumption. To the best of my knowledge this test has never been employed for Brazil. Indeed, the papers that have analyzed consumption behavior in Brazil are, habitually, based on Campbell and Mankiw's (1989, 1990) approach, in which a fraction of consumers follow a rule of thumb: they consume their current income instead of their permanent income, possibly due to liquidity constraints. For instance, Cavalcanti (1993), Reis et al (1998), Issler and Rocha (2000), Gomes and Paz 
(2004), Gomes (2004) and Gomes et al (2005) found evidence in favor of rule-of-thumb behavior. The presence of rule-of-thumb behavior should lead the direct test to reject the PIH. The intuition is obvious: if some agents consume the current income, then the impact of income on consumption revision will be different from that predicted by PIH. They can be coincidently similar only if current income equals permanent income, but this is improbably, especially during the entire period, from 1947 to 2010.

The paper is organized as follows. The second section presents the literature review. The third section presents the derivation of the direct test of permanent income. The forth section presents the data set, while the fifth section reports the results. Finally, the last section summarizes the main findings.

\section{LITERATURE REVIEW}

Following Hall (1978), the rational and forward-looking consumer maximizes her utility by solving the following problem:

$$
\begin{array}{r}
\operatorname{Max}_{\substack{\left\{c_{t+i}\right\}_{i=0}^{\infty} \\
\text { s.t. }}} E_{t}\left\{\sum_{t+1+i}^{\infty}=\left(W_{t+i}\left[\beta^{i} u\left(C_{t+i}\right)\right]\right\},\right. \\
\end{array}
$$

where $C_{t}, W_{t}, Y_{t}$, e $r_{t}$ are, respectively, consumption, wealth, income, and real interest rate in period $t$, while $\beta$ is the discount factor. Thus, subject to the budget constraint, the consumers optimize their entire stream of consumption. Additionally, Hall (1978) assumed a quadratic utility and that interest rate equals the reciprocal of the discount factor, leading to the consumption random walk hypothesis: $C_{t}=C_{t-1}+\varepsilon_{t}$, where $\varepsilon_{t}$ is the error term. This term is an innovation, i.e. $E_{t-1}\left(\varepsilon_{t}\right)=0$. In this vein, exante consumption is constant, being perfectly smoothed; however, ex-post consumption revisions are proportional to innovations. While Friedman (1957) put forward the PIH, arguing that consumers smooth consumption, Hall (1978) was the first to relate the PIH with the consumer intertemporal problem.

Studying the US case, Campbell and Mankiw $(1989,1990)$ extend the basic model, considering two types of consumers: 1) one that follows the $\mathrm{PIH}$; 2) another that follows a rule of thumb, consuming the current income. This behavior might occur as a consequence of liquidity constraints; consumers would like to smooth out their consumption, but they 
are not able to due to a lack of credit. See, for instance, Vaidyanathan (1993), Engelhardt (1996), Sarantis and Stewart (2003) and Brady (2008). ${ }^{1}$

To examine the relevance of each consumer type, Campbell and Mankiw (1989, 1990) estimated the impact of anticipated income change on consumption revision, by means of equation: $\Delta C_{t}=\mu+\lambda \Delta Y_{t}^{a}+\varepsilon_{t}$, where $\Delta$ is the first difference operator, $\Delta C_{t}$ is the consumption revison, $\Delta Y_{t}^{a}$ is the anticipated income change, and $\varepsilon_{t}$ is the error term. The coefficient $\lambda$ measures the intensity of rule-of-thumb behavior, because under PIH the consumption revision should not depend on predicted income. For instance, using G7 data, Campbell and Mankiw concluded that rule-of- thumb behavior was widespread. For the U.S. economy, about $50 \%$ of total income belongs to rule-of-thumb consumers. Indeed, very early Flavin (1981) stated that PIH is rejected because consumption is excessively sensitive to current income and Flavin (1985) suggested that this result comes from liquidity constraints.

There is an extensive literature for Brazil that employs Campbell and Mankiw's (1989, 1990) model and the findings strongly support the contention that consumers present the rule-of-thumb behavior. Cavalcanti (1993) estimated $\lambda$ around 0.32, Reis et al's (1998) findings stated that $\lambda$ is approximately 0.8, while Issler and Rocha (2000), Gomes and Paz (2004) and Gomes (2004) obtained average $\lambda$ s equal to 0.74, 0.61 and 0.85, respectively. Based on a series of durable consumption, Gomes et al (2005) also found strong evidence in favor of rule-of-thumb behavior. ${ }^{2}$

\section{PERMANENT INCOME INNOVATIONS AND CONSUMPTION REVISIONS}

Following Dejuan et al (2004), the standard permanent income model is given by:

$$
\begin{aligned}
C_{t} & =Y_{t}^{P} \\
Y_{t}^{P} & =r W_{t}+\frac{r}{1+r} \sum_{j=0}^{\infty} \frac{1}{(1+r)^{j}} E_{t}\left(Y_{t+j}\right) \\
W_{t} & =(1+r) W_{t-1}+Y_{t-1}-C_{t-1}
\end{aligned}
$$

where $C_{t}, Y_{t}^{P}, W_{t}, Y_{t}$ are, respectively, consumption, permanent income, nonhuman wealth and labor income, $r$ is the real interest rate and $E_{t}(\cdot)$ is the expectation operator conditional on information available to consumers during period $t$. The additional 
assumptions are: the real interest rate is constant and identical to the intertemporal discount factor and income is exogenous. Thus, it is possible to show that permanent income changes are only due to new information about future labor income:

$$
\Delta Y_{t}^{P}=\frac{r}{(1+r)} \sum_{j=0}^{\infty} \frac{1}{(1+r)^{j}}\left(E_{t}-E_{t-1}\right) Y_{t+j} \equiv \gamma_{t}
$$

where $\Delta=1-L$ is the difference operator and $L$ is the lag operator. This result means that revisions on permanent income are equal to the annuity value of revisions in the expected future income. Once consumption is equal to permanent income, by equation 1 , we obtain:

$$
\Delta C_{t}=\Delta Y_{t}^{P}=\gamma_{t}
$$

Therefore, income innovation causes the same size revision in consumption as in permanent income. As discussed by Dejuan et al (2004), this implication can be tested if we assume any model for income, in order to calculate the revisions $\left(E_{t}-E_{t-1}\right) Y_{t}$. Following Flavin (1981) and Dejuan et al (2004), I suppose that income is an $\operatorname{ARIMA}(\mathrm{p}, 1, \mathrm{q})$ process: $^{3}$

$$
\left(1-\phi_{1} L-\cdots-\phi_{p} L^{p}\right) \Delta Y_{t}=\left(1+\theta_{1} L+\cdots+\theta_{k} L^{k}\right) \varepsilon_{t}
$$

As showed by Flavin (1981), the revisions in permanent income are given by:

$$
\gamma_{t}=\gamma(r, \Phi, \Theta) \varepsilon_{t}, \quad \gamma(r, \Phi, \Theta)=\frac{1+\sum_{j=1}^{\infty} \frac{\theta_{j}}{(1+r)^{j}}}{1-\sum_{j=1}^{\infty} \frac{\phi_{j}}{(1+r)^{j}}}
$$

where $\Phi=\left(\begin{array}{llll}\phi_{1} & \phi_{2} & \cdots & \phi_{p}\end{array}\right)$ and $\Theta=\left(\begin{array}{llll}\theta_{1} & \theta_{2} & \cdots & \theta_{q}\end{array}\right)$. According to the PIH, the marginal propensity to consume due to an income innovation $\varepsilon_{t}$ should be equal to $\gamma$, the marginal propensity to revise permanent income in response to that innovation. Therefore, 
they are conditional in relation to the ARMA coefficients and the real interest rate and $\gamma$ provides a direct measure of the impact on permanent income caused by the innovation in current income. For instance, consider the $\operatorname{AR}(1)$ case. The coefficient $\gamma$ becomes $1 /\left[1-\phi_{1} /(1+r)\right]$ and, for a given interest rate, if $\phi_{1}>0$, then $\gamma>1$. If positive shocks tend to be followed, on average, by others positive shocks, then there is persistence and $\gamma$ is greater than 1.

Finally, after I estimate the ARMA model for $\Delta Y_{t}$, it is possible to obtain a measure of the innovation $\varepsilon_{t}$ and estimate the model:

$$
\Delta C_{t}=\beta \varepsilon_{t}+\vartheta_{t}
$$

and, as discussed by Dejuan et al (2004), it is possible to test if $\beta=\gamma(r, \Phi, \Theta)$. Thus, a direct way to test the $\mathrm{PIH}$, is given by the following hypothesis test

$$
\begin{aligned}
& H_{0}: \beta=\gamma(r, \Phi, \Theta) \\
& H_{A}: \beta \neq \gamma(r, \Phi, \Theta)
\end{aligned}
$$

Conditional on a value for $r$, equations 6 and 8 can be estimated as a system, and a Wald test can be used to conduct this test. Dawson et al (2001) performed a direct test for a group of countries, using a similar approach. After estimating $\beta$ and $\gamma$ for $N$ countries, the authors estimated the regression: $\beta_{i}=\alpha_{0}+\alpha_{1} \gamma_{i}+\zeta_{i}$ for $i=1, \ldots, N$. Of course, $\beta$ is equal to $\gamma$ across countries when $\alpha_{0}=0$ and $\alpha_{1}=1$. However, this methodology does not apply for a single country. Hence, I followed Dejuan et al's (2004) approach.

\section{DATA}

Choosing the data set is an important decision. Dawson et al (2001) investigated carefully the errors-in-variable problem using Penn World Table (PWT) data. They argued that income innovation can be measured with error due to the poor quality of data for some countries. Indeed, they found the PIH was rejected for poor quality data countries, and found the opposite result for high quality data ones. Thus, it seems that empirical results may be driven by data quality. It is worth mentioning that, from grades A to D, PWT gives 
a grade $\mathrm{C}$ to Brazil. Thus, I used the National Bureau of Geography and Statistics (Instituto Brasileiro de Geografia e Estatística - IBGE) data, extracted from IPEADATA (www.ipeadata.gov.br/). We should expect a major problem with the PWT when compared to the IBGE data, because the PWT has an additional step: the data must be transformed into PPP.

From IPEADATA, I obtained the consumption series which is household final consumption, while the income series is the gross disposable income, both given annually, for the period from 1947 to 2010 . The real per capita series was obtained using the resident mid-period population and the implicit price deflator from the gross domestic product. Graph 1 presents the real consumption per capita - hereafter consumption - and real per capita income - hereafter income. These series present a similar pattern.

\section{Graph 1 - Consumption and Income Evolution}

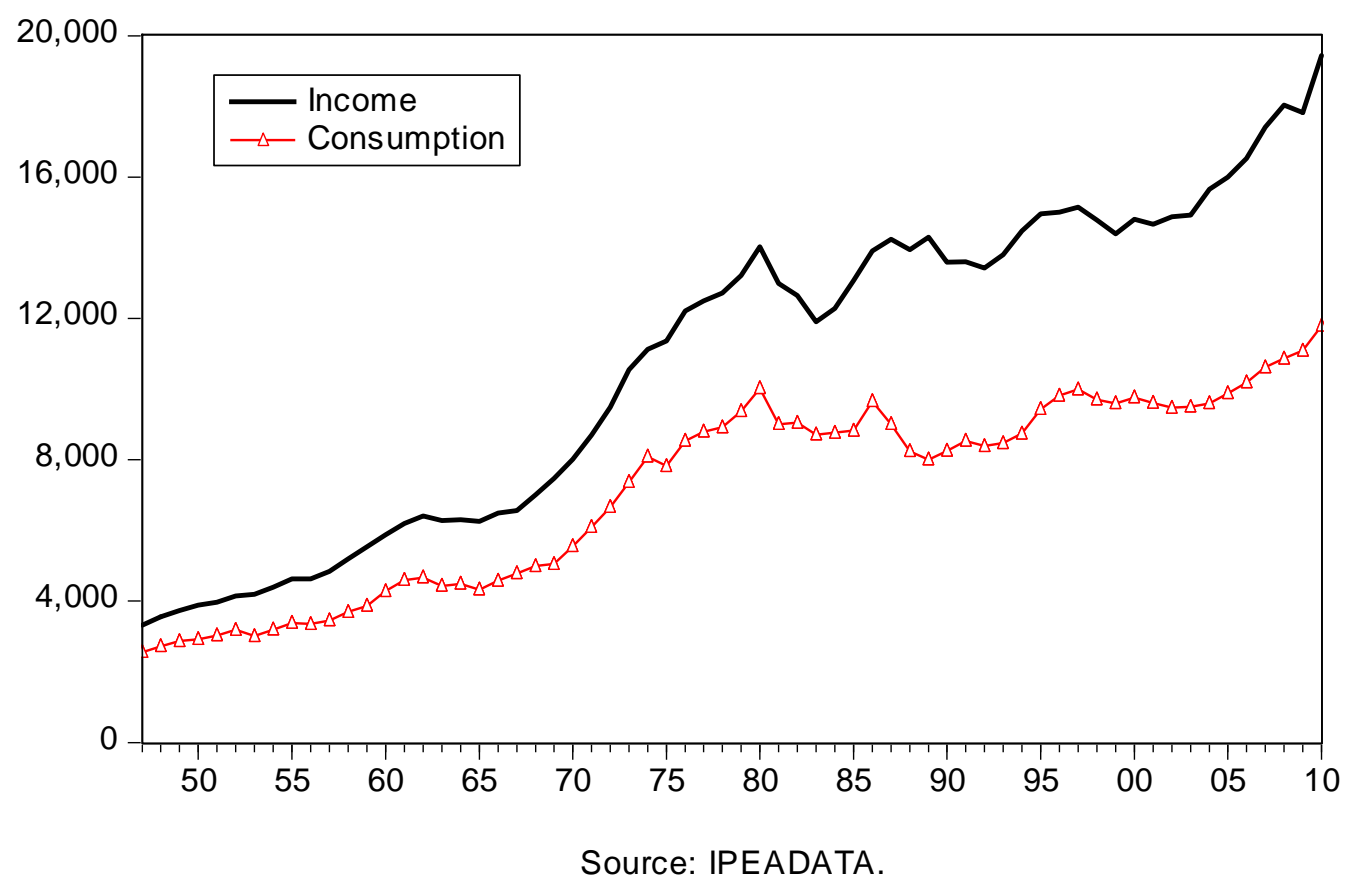

The Graph 2 presents the first difference of consumption and income. As can be seen, there is a clear correlation between both. The correlation is 0.702 , being relevant at $1 \%$ significance level. This correlation is consistent with PIH only if current income is strongly related to permanent income; but, it is compatible with rule-of-thumb behavior. 
Graph 2 - Consumption and Income First Difference

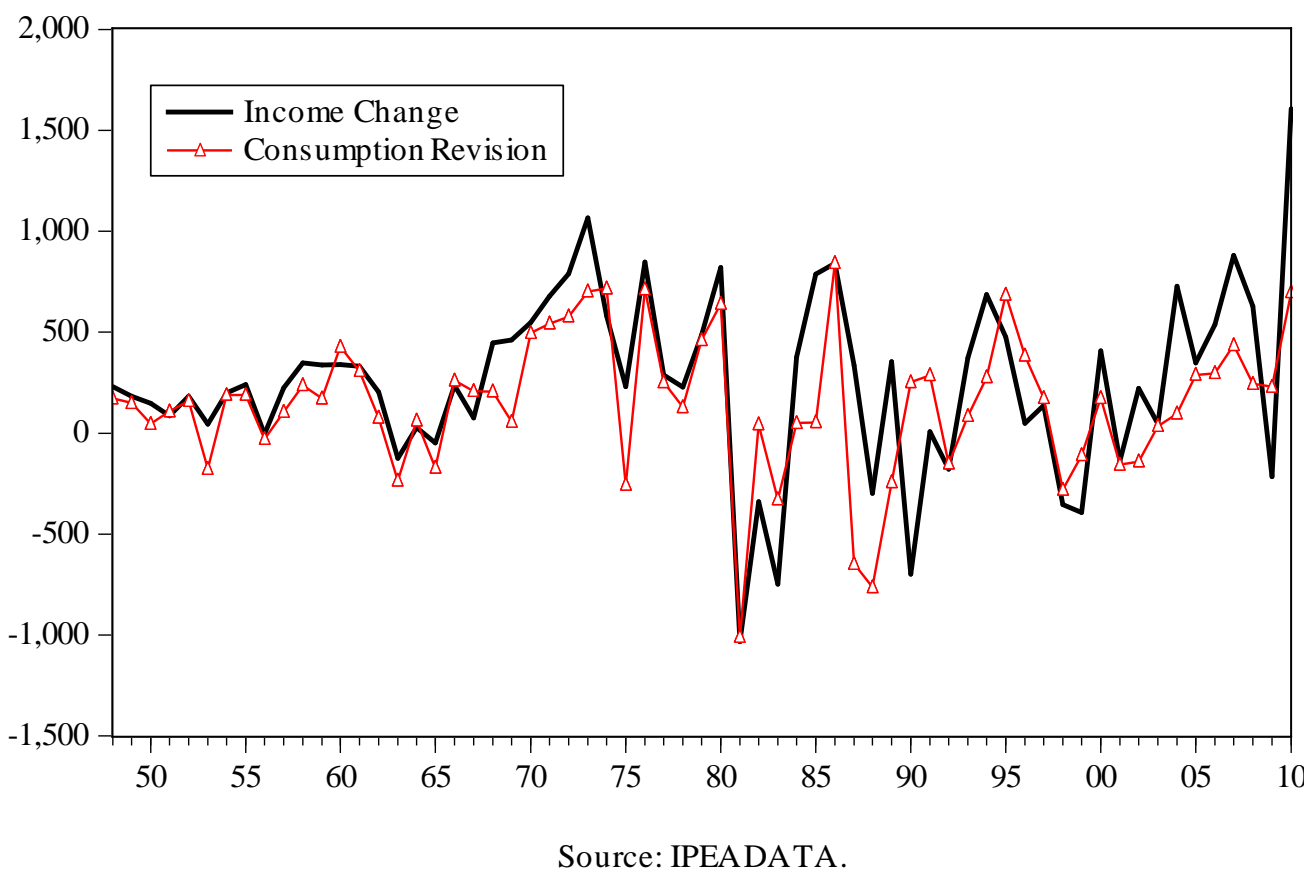

\section{RESULTS FROM THE DIRECT TEST}

First of all, I examined the order of integration of consumption and income by means of three unit root tests: augmented Dickey-Fuller (ADF); Phillips-Perron (PP) and Kwiatkowski-Phillips-Schmidt-Shin (KPSS). See Dickey and Fuller (1979), Phillips and Perron (1988) and Kwiatkowski et al (1992). While with ADF and PP the null hypothesis is the presence of a unit root, KPSS assumes stationarity under the null hypothesis. The results of these tests are reported in Table 1. When series are in level two options were used for the deterministic components: i) constant; ii) constant plus a linear trend. For the first difference only a constant was included. The ADF and PP tests did not reject the unit root null hypothesis at the $5 \%$ level for consumption and income, but they did for their first difference series. The KPSS rejected the stationarity null hypothesis at the $5 \%$ level for consumption and income. The opposite result was obtained for consumption and income first differences. Summing up, these results suggest that consumption and income are integrated series. More specifically, they are I(1) processes. 
Table 1 - Unit Root Tests

\begin{tabular}{|c|c|c|c|c|}
\hline \multirow{2}{*}{ Series } & \multirow{2}{*}{ Deterministic Terms } & \multicolumn{3}{|c|}{ Statistics } \\
\hline & & $\mathrm{ADF}$ & $\mathrm{PP}$ & KPSS \\
\hline$C_{t}$ & Constant & -0.4688 & -0.54097 & $0.8960 *$ \\
\hline$C_{t}$ & Constand and trend & -1.4896 & -1.75631 & $0.1598 * *$ \\
\hline$Y_{t}$ & Constant & 0.2419 & 0.02747 & $0.9478^{*}$ \\
\hline$Y_{t}$ & Constand and trend & -1.8585 & -1.86872 & $0.1475 * *$ \\
\hline$\Delta C_{t}$ & Constant & $-6.2951^{*}$ & $-6.29511^{*}$ & 0.0891 \\
\hline$\Delta Y_{t}$ & Constant & $-5.4210 *$ & $-5.3657 *$ & 0.0896 \\
\hline
\end{tabular}

Thus, it is appropriate to estimate an ARMA process for $\Delta Y_{t}$. Dawson et al (2001) and Dejuan et al (2004) considered two models: AR(1) and AR(2). Differently from them, I estimated $16 \operatorname{ARMA}(\mathrm{p}, \mathrm{q})$ models with all combinations of $p, q \leq 2$. The three information criteria used - Schwarz (SIC), Akaike (AIC) and Hannan-Quinnn (HQIC) -, lead to the same MA(2) model: $\Delta Y_{t}=\mu+\theta_{2} \varepsilon_{t-2}+\varepsilon_{t}$. The second model selected by the SIC was the AR(1): $\Delta Y_{t}=\mu+\phi_{1} \Delta Y_{t-1}+\varepsilon_{t}$. And, the second model selected by AIC and HQIC was the same, the following $\operatorname{ARMA}(1,2): \Delta Y_{t}=\mu+\phi_{1} \Delta Y_{t-1}+\theta_{2} \varepsilon_{t-2}+\varepsilon_{t}$. Table 2 displays the results, including the diagnostic tests. We employed the Ljung-Box Q-statistic for serial correlation calculated for 28 lags and the serial correlation LM test calculated sequentially from 1 to 4 lags. The null hypothesis of absence of serial correlation was not rejected for any model. Last, the $\mathrm{LM} \mathrm{ARCH}$ test for autoregressive conditional heteroskedasticity in the residuals was conducted sequentially from 1 to 4 lags and, only the MA(2) model showed signs of heterocedasticity at 5\% significance level.

Based on previous results the $\operatorname{AR}(1)$ and $\operatorname{ARMA}(1,2)$ models present better performance than the $\mathrm{MA}(2)$. However, before electing the best model, we check if the models generate income innovations similar or distinct. Graph 3 displays the relation between each innovation measure and consumption revision. The income innovation is very similar across the models and there is clear evidence of a positive relation with the consumption change. But, is this relation in accordance with the PIH? To answer this question, it is necessary to test if $\beta=\gamma$. 
Table 2 -ARMA models for Income First Difference

\begin{tabular}{|c|c|c|c|c|c|c|}
\hline \multirow{3}{*}{ Model } & \multirow{2}{*}{\multicolumn{3}{|c|}{$\begin{array}{l}\text { Estimated Coefficient } \\
\text { (Std. Errors) }\end{array}$}} & \multicolumn{3}{|c|}{ Rejection of the Null Hypothesis at $5 \%$} \\
\hline & & & & $\begin{array}{c}\mathrm{H}_{0}: \mathrm{N} \\
\text { Corr }\end{array}$ & $\begin{array}{l}\text { Serial } \\
\text { ation }\end{array}$ & $\mathrm{H}_{0}$ : Homoskedasticity \\
\hline & $\mu$ & $\phi_{1}$ & $\theta_{2}$ & Q & LM & $\mathrm{ARCH}$ \\
\hline $\operatorname{AR}(1)$ & $\begin{array}{l}265.2409 \\
(79.3040)\end{array}$ & $\begin{array}{c}0.2539 \\
(0.1227)\end{array}$ & & $\begin{array}{l}\mathrm{H}_{0} \text { is not } \\
\text { rejected }\end{array}$ & $\begin{array}{l}\mathrm{H}_{0} \text { is not } \\
\text { rejected }\end{array}$ & $\mathrm{H}_{0}$ is not rejected \\
\hline $\operatorname{ARMA}(1,2)$ & $\begin{array}{l}268.5742 \\
(87.7045)\end{array}$ & $\begin{array}{c}0.1779 \\
(0.1502)\end{array}$ & $\begin{array}{c}0.2931 \\
(0.0001)\end{array}$ & $\begin{array}{c}\mathrm{H}_{0} \text { is not } \\
\text { rejected }\end{array}$ & $\begin{array}{l}\mathrm{H}_{0} \text { is not } \\
\text { rejected }\end{array}$ & $\mathrm{H}_{0}$ is not rejected \\
\hline $\operatorname{MA}(2)$ & $\begin{array}{l}262.7302 \\
(81.6341)\end{array}$ & & $\begin{array}{c}0.3307 \\
(0.0001)\end{array}$ & $\begin{array}{l}\mathrm{H}_{0} \text { is not } \\
\text { rejected }\end{array}$ & $\begin{array}{l}\mathrm{H}_{0} \text { is not } \\
\text { rejected }\end{array}$ & $\mathrm{H}_{0}$ is rejected \\
\hline
\end{tabular}

Note: Standard errors are in parenthesis. Q means Ljung-Box Q statistic for serial correlation calculated for 28 lags. LM means serial correlation LM test calculated sequentially from 1 to 4 lags. ARCH means the LM $\mathrm{ARCH}$ test for autoregressive conditional heteroskedasticity in the residuals.

Graph 3 - Income Innovation and Consumption Change

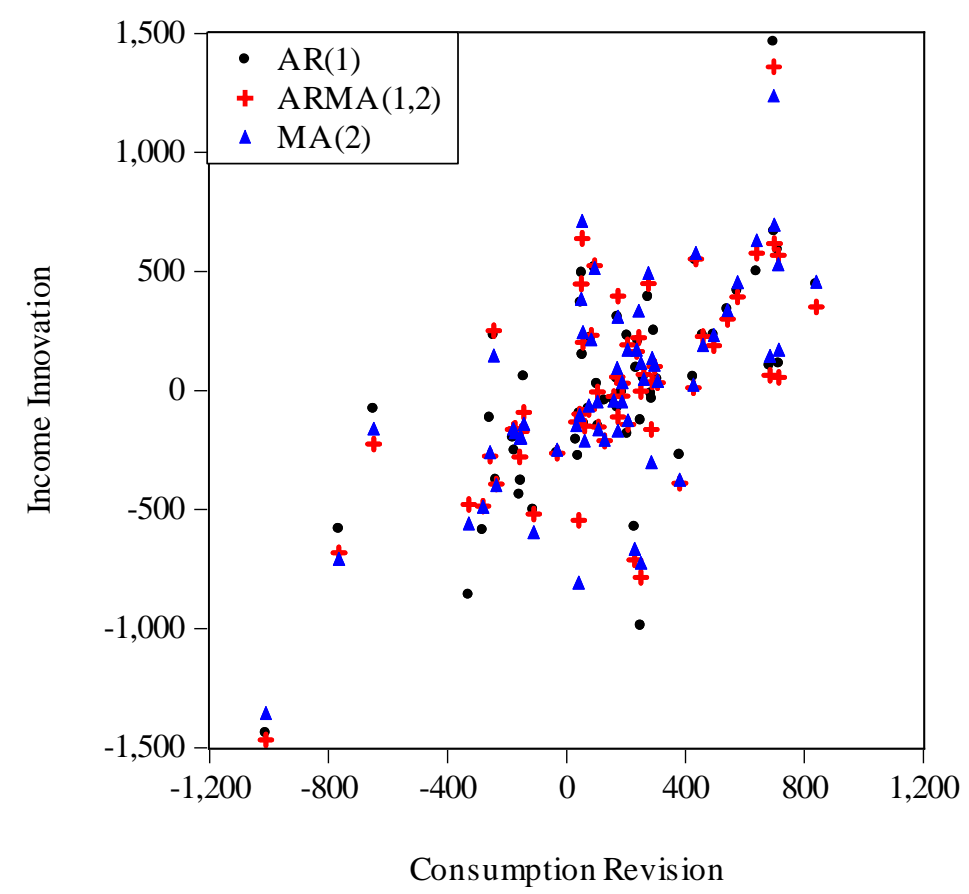

First of all, we estimated the following systems:

$$
\begin{aligned}
\Delta C_{t} & =\beta_{1}(A R(1) \text { innovation })+\xi_{1 t} \\
\Delta C_{t} & =\beta_{2}(A R M A(1,2) \text { innovation })+\xi_{2 t} \\
\Delta C_{t} & =\beta_{3}(M A(2) \text { innovation })+\xi_{3 t}
\end{aligned}
$$


And,

$$
\begin{aligned}
\Delta C_{t} & =\mu_{1}+\beta_{1}(\text { AR(1) innovation })+\xi_{1 t} \\
\Delta C_{t} & =\mu_{2}+\beta_{2}(\text { ARMA }(1,2) \text { innovation })+\xi_{2 t} \\
\Delta C_{t} & =\mu_{3}+\beta_{3}(\text { MA(2) innovation })+\xi_{3 t}
\end{aligned}
$$

The results are reported in Table 3. The results suggested that the three income innovation measure generate very similar coefficients, no matter if a constant is included or not in each equation. In both systems we test the null hypothesis $H_{0}: \beta_{1}=\beta_{2}=\beta_{3}$, using a Wald test and the null hypothesis is not rejected at any usual significance level. Thus, from now on we just analyze the $\operatorname{AR}(1)$ case for two reasons. First, we can estimate $\beta$ and the AR(1) coefficients together, as done by Dejuan et al (2004). Second, the MA(2) model showed signs of heteroskedasticity and the $\operatorname{ARMA}(1,2)$ model was chosen by the AIC, which is not consistent and tend to overestimate the number of coefficients (ARMA terms).

Table 3 - System Estimation by OLS

\begin{tabular}{lcc}
\hline & $\begin{array}{c}\text { System (9) } \\
\text { Coefficient }\end{array}$ & $\begin{array}{c}\text { System (10) } \\
\text { Coefficient }\end{array}$ \\
\hline$\beta_{1}$ & 0.5510 & 0.5510 \\
& $(0.0892)$ & $(0.0783)$ \\
$\beta_{2}$ & 0.5507 & 0.5518 \\
& $(0.0927)$ & $(0.0817)$ \\
$\beta_{3}$ & 0.5579 & 0.5591 \\
& $(0.0902)$ & $(0.0791)$ \\
\hline Wald Test: $H_{0}: \beta_{1}=\beta_{2}=\beta_{3}$ & \\
Statistic & 0.0040 & 0.0063 \\
P-value & 0.9980 & 0.9969 \\
\hline
\end{tabular}

Note: Standard errors in parenthesis.

Finally, to accomplish this task, the Non-linear Least Squares estimator was used in order to estimate the following system:

$$
\begin{gathered}
\Delta Y_{t}=\mu+\phi_{1} \Delta Y_{t-1}+\varepsilon_{t} \\
\Delta C_{t}=\beta \varepsilon_{t}+\vartheta_{t}
\end{gathered}
$$


Once $\varepsilon_{t}$ is not observable using equation 11 , it is replaced in equation 12 , in order to make the estimation of the system feasible. Equation (12) becomes $\Delta C_{t}=\beta\left(\Delta Y_{t}-\mu-\phi_{1} \Delta Y_{t-1}\right)+\vartheta_{t}$. It is worth mentioning that it is not necessary to assume any value for $r$ to estimate the system. The results are presented in Table 4. First of all, notice that $\hat{\phi}_{1}$ is 0.180 , being significant at the $10 \%$ level. If $\gamma=\beta$, once $\hat{\phi}_{1}>0$, equation 7 implies that $\gamma$ should be greater than 1 . However, $\hat{\beta}$ is lower than 1 . Indeed, the $\mathrm{p}$-value of the hypothesis test $H_{0}: \beta=1$ against $H_{A}: \beta<1$, is lower than $1 \%$, for any interest rate used. Thus, the null hypothesis is always rejected, even at a $1 \%$ level of significance.

Table 4 -Estimation by NLS: Equations (11) and (12)

\begin{tabular}{cccc}
\hline Parameter & Coefficient & Std. Error & P-value \\
$\mu$ & 149.7050 & 46.3925 & 0.0016 \\
$\phi_{1}$ & 0.1798 & 0.0992 & 0.0726 \\
$\beta$ & 0.5969 & 0.1081 & 0.0000 \\
\hline Interest Rate & Implied & Wald Test: $H_{0}: \beta=\gamma$ \\
$\mathrm{r}$ & $\gamma(r, \Phi, \Theta)$ & Statistic & P-value \\
$-50 \%$ & 1.5613 & 3.8426 & 0.0500 \\
$-25 \%$ & 1.3152 & 8.2800 & 0.0040 \\
$-15 \%$ & 1.2682 & 9.9030 & 0.0017 \\
$-5 \%$ & 1.2334 & 11.3408 & 0.0008 \\
$5 \%$ & 1.2066 & 12.5721 & 0.0004 \\
$15 \%$ & 1.1853 & 13.5989 & 0.0002 \\
$25 \%$ & 1.1680 & 14.4376 & 0.0001 \\
$35 \%$ & 1.1536 & 15.1110 & 0.0001 \\
$45 \%$ & 1.1415 & 15.6442 & 0.0001 \\
$90 \%$ & 1.1045 & 16.8821 & 0.0000 \\
$135 \%$ & 1.0848 & 17.1495 & 0.0000 \\
\hline
\end{tabular}

Note: Implied $\gamma$ means the $\gamma$ calculated based in equation 7 and the estimates for $\phi_{1}$. We test if $\beta=\gamma(r, \Phi, \Theta)$ using different values for $r$ and, in all cases, the null hypothesis was rejected.

Finally, to test if $\beta=\gamma(r, \Phi, \Theta)$, different values for $r$ were used and, for each one, a Wald test was conducted. ${ }^{4}$ Appendix A1 explains the grid used for $r$. The interest rate assumed eleven values, varying from $-50 \%$ to $135 \%$. Thus, eleven tests were done. Table 4 presents the implied value for $\gamma$, i.e. $1 /\left[1-\widehat{\phi}_{1} /(1+r)\right]$, and the statistic and p-value of the Wald test. For any value of the interest rate, the null hypothesis was rejected at a $10 \%$ level 
of significance. ${ }^{5}$ Except for extreme low interest rate value; the null hypothesis was rejected at a $1 \%$ level of significance. Thus, at the end, the PIH is rejected.

\section{CONCLUSION}

This paper analyzes whether the PIH is able to explain consumptions revisions. To accomplish this investigation, I estimated an ARMA process for income first differences in order to obtain a measure of the amount of permanent income innovation. The findings reveal that revisions in consumption are statistically different from innovations in permanent income. Therefore, the PIH was rejected by this direct test. The literature documented that a fraction of Brazilian consumers follows a simple rule-of-thumb: consume current income. In this case, we should not expect this theory to prevail.

In any case, the methodology used here has some advantages. Differently from most part of the literature, including Campbell and Mankiw's (1989, 1990) approach, It was not necessary to assume a CRRA utility or a log-linearization of the Euler Equation. On the other hand, the assumption of ARIMA processes for income carries the underlying hypothesis that consumers use only past income to predict future income. However, West (1988), Quah (1990) and Flavin (1993) argued that consumers may also use additional information in order to forecast income more accurately. In this vein, the extension of the direct test using a multivariate model to predict income is left for future research.

\section{REFERENCES}

ANGELETOS, G. et al. The hyperbolic consumption model: calibration, simulation, and empirical evaluation. Journal of Economic Perspectives, v. 15, n. 3, p. 47-68, 2001.

BILSON, J. The rational expectation approach to the consumption function: a multicountry study. European Economic Review, v. 13, n. 3, p. 273-299, maio1980.

BRADY, Ryan R. Structural breaks and consumer credit: is consumption smoothing finally a reality? Journal of Macroeconomics, v. 30, n. 3, p. 1246-1268, set. 2008.

CAMPBELL, J.; MANKIW, G. Consumption, income and interest rates: reinterpreting the time series evidence. In: BLANCHARD, O. J.; STANLEY, Fischer (Ed.) NBER Macroeconomics Annual, v. 4, p. 185-216. Cambridge, MA: MIT Press, 1989.

CAMPBELL, J.; MANKIW, N. Permanent income, current income and consumption. Journal of Business and Economic Statistics, v. 8, n. 3, p. 265-280, jul. 1990.

CARROL, C. Buffer-stock saving and the life cycle/permanent income hypothesis. Quarterly Journal of Economics, v. 112, n. 1, p. 1-55, fev. 1997. 
CAVALCANTI, C. Intertemporal substitution in consumption: an empirical investigation for Brazil. Brazilian Review of Econometrics, 13, 203-229, 1993.

DEJUAN, J.; SEATER, J.; WIRJANTO, T. A direct test of the permanent income hypothesis with an application to the U.S. states. Journal of Money, Credit and Banking, v. 36, n. 6, p. 1091-1103, dez. 2004.

DAWSON, J. et al. Economic information versus quality variation in cross-country data. Canadian Journal of Economics, v. 34, n. 4, p. 988-1009, nov. 2001.

DICKEY, D.; FULLER, W. Distribution of the estimators for autoregressive time series with a unit root. Journal of the American Statistical Association, v. 74, n. 366, p. 427 431, jun. 1979.

ENGELHARDT, Gary V. Consumption, down payments and liquidity constraints. Journal of Money, Credit and Banking, v. 28, n. 2, p. 255-271, maio 1996.

EZEALA-HARRISON, F.; BAFFOE-BONNIE, J. Theoretical and empirical issues in national income and consumption planning in LDCs. Journal of Economic Development, v. 19, n. 2, p. 117-137, 1994.

FLAVIN, M. The adjustment of consumption to changing expectations about future income. Journal of Political Economy, v. 89, n. 5, p. 974-1009, out. 1981.

FLAVIN, Marjorie. Excess sensitivity of consumption to current income: liquidity constraints or myopia? Canadian Journal of Economics, v. 18, n. 1, p. 117-36, fev. 1985.

The excess smoothness of consumption: identification and interpretation. Review of Economic Studies, v. 60, n. 3, p. 651-666, jul. 1993.

FRIEDMAN, M. A theory of consumption function. Princeton: Princeton University Press, 1957.

GOMES, F. Consumo no Brasil: teoria da renda permanente, formação de hábito e restrição à liquidez. Revista Brasileira de Economia, v. 58, n. 3, p. 381-402, jul. 2004.

GOMES, F.; ISSLER, J.; SALVATO, M. Principais características do consumo de duráveis no Brasil e testes de separabilidade entre duráveis e não duráveis. Revista Brasileira de Economia, v. 59, n. 1, p. 33-60, jan./mar. 2005.

GOMES, F., PAZ, L. Especificações para a função consumo: testes para países da América do Sul. Pesquisa e Planejamento Econômico, v. 34, n. 1, p. 39-55, 2004.

HALL, R. Stochastic implications of the life cycle permanent income hypothesis: theory and evidence. Journal of Political Economy, v. 86, n. 6, p. 971-87, dez. 1978.

ISSLER, J.; ROCHA, F. Consumo, restrição a liquidez e bem-estar no Brasil. Economia Aplicada, v. 4, p. 637-665, out./dez. 2000.

KWIATKOWSKI, D. et al. Testing the null hypothesis of stationarity against the alternative of a unit root. Journal of Econometrics, v. 54, n. 1-3, p. 159-178, out./dez. 1992. 
MANKIW, N., SHAPIRO, M. Trends, random walks, and tests of the permanent income hypothesis. Journal of Monetary Economics, v. 16, n. 2, p.165-174, set. 1985.

PHILLIPS, P.; PERRON, P. Testing for a unit root in time series regression. Biometrika, v. 75, n. 2, p. 335-346, 1988.

QUAH, D. Permanent and transitory movements in labor income: an explanation for excess smoothness in consumption. Journal of Political Economy, v. 98, n. 3, p. 449-475, jun. 1990.

REIS, E. et al. Renda permanente e poupança precaucional: evidências empíricas para o Brasil no passado recente. Pesquisa e Planejamento Econômico, v. 28, n. 3, p. 233-272, dez.1998.

SARANTIS, N.; STEWART, C. Liquidity constraints, precautionary saving and aggregate consumption: an international comparison. Economic Modelling, v. 20, n. 6, p. 11511173, dez. 2003.

VAIDYANATHAN, Geetha. Consumption, liquidity constraints and economic development. Journal of Macroeconomics, v. 15, n. 3, p. 591-610, 1993.

WEISSENBERGER, E. Consumption innovations and income innovations: evidence from United Kingdom and Germany. The Review of Economics and Statistics, v. 68, n. 1, p. $1-8,1986$.

WEST, K. The insensitivity of consumption to news about income. Journal of Monetary Economics, v. 21, n. 1, p. 17-34, jan. 1988.

\section{NOTES}

1. Others explanations include buffer stock savings (Carrol, 1997) and self-control problems (Angeletos et al., 2001), for instance.

2. Vaidyanathan (1993) used the Penn World Table (Summer and Heston, 1988) to estimate $\lambda$ for fifty-nine countries, including Brazil, which presented a value of 0.70. Ezeala-Harrison and Baffoe-Bonnie (1994) analyzed the consumption random-walk hypothesis, which means that consumption growth rate should not depend on income growth rate, finding stronger evidence against this hypothesis for low-income countries. Although the Brazil was not analyzed, this result is in line with rule-of-thumb behavior and its interpretation as a measure of lack of credit.

3. Indeed, in the next section I test if income is an I(1) process, but to save space only the differencestationary case is presented.

4. The Delta method was used to estimate the variance of $\beta-\gamma(r, \Phi, \Theta)$, using analytic derivatives.

5. Equations (11) and (12) were also estimated by GMM, as suggested by a referee. The coefficients obtained were very similar to those reported in Table 4 and, the Wald tests for $\gamma=\beta$ rejected the null hypothesis, at a $1 \%$ level of significance, for any value of the interest rate. Therefore, the PIH is rejected. These results are available upon request. 


\section{APPENDIX A1}

The grid for the interest rate was done based on Table A1, which displays the descriptive statistics for three assets: Ibovespa, $\mathrm{CDB}$ and Selic. The real series was obtained using the implicit price deflator from the gross domestic product. The data was extracted from IPEADATA. Differently from consumption series, available since 1947, the IPEADATA displays these returns, basically, since 1970. In any case, since we consider a very large grid for the interest rate, this does not seem to be a major problem. Consumer decision is based on expected return instead of realized return. If we use the average value of each asset as a proxy for expected return, the grid must range from, approximately, $8 \%$ to $31 \%$. Using the median, the range becomes, approximately, $3 \%$ to $8 \%$. However, using the percentiles 0.25 and 0.75 , any index is greater than $-25 \%$ and less than $45 \%$, approximately. The grid used is based on these values, being homogeneous with interval equals to $10 \%$. In addition, the values $-50 \%, 90 \%$ and $135 \%$ were included, due to the tails of the distribution of Ibovespa.

Table A1 - Annual Real Return

\begin{tabular}{lcccc}
\hline Asset & & Ibovespa & CDB & SELIC \\
\hline Period & & $1969-2010$ & $1970-2009$ & $1974-2010$ \\
\hline \multirow{4}{*}{ Percentiles } & 0.10 & $-48.65 \%$ & $-18.89 \%$ & $-22.07 \%$ \\
& 0.25 & $-23.09 \%$ & $-1.96 \%$ & $-2.38 \%$ \\
& 0.50 & $2.97 \%$ & $5.54 \%$ & $7.80 \%$ \\
& 0.75 & $42.89 \%$ & $11.52 \%$ & $15.93 \%$ \\
Average & 0.90 & $131.05 \%$ & $45.18 \%$ & $48.90 \%$ \\
\hline
\end{tabular}

*The author acknowledges the financial support of CNPq-Brazil. 